\title{
Epidemiological Study on the Prevalence of Asymptomatic Malaria Parasite among Pregnant Women Attending Antenatal Clinic at Mariya Sunusi Maternity Hospital Kano, Nigeria
}

\author{
Ahmad Salisu Aliyu ${ }^{1, *}$, Ahmed Habibu Badawi ${ }^{1}$, Hussaini Mohammed ${ }^{2}$, Nuru Yakubu Umar ${ }^{3}$, Samira \\ $\mathrm{Shehu}^{4}$ \\ ${ }^{I}$ Medical Laboratory Department Infectious Diseases Hospital (IDH) Kano, Nigeria \\ ${ }^{2}$ College of Nursing Sciences, Abubakar Tafawa Balewa University Teaching Hospital Bauchi, Bauchi State, \\ Nigeria \\ ${ }^{3}$ College of Nursing and Midwifery, Bauchi State, Nigeria \\ ${ }^{4}$ Medical Laboratory Department Mariya Sunusi Maternity Hospital Kano, Nigeria
}

*Corresponding Author: Ahmad Salisu Aliyu, Medical Laboratory Department Infectious Diseases Hospital (IDH) Kano, Nigeria. E-mail: salisuahmadaliyu@yahoo.com

\begin{abstract}
Background: According to World Health Organization Malaria are a major public health problem and an important cause of maternal and infant morbidity in sub-Saharan Africa, including Nigeria. Malaria during pregnancy remains a major public health threat in sub-Saharan Africa where about 125 million pregnancies are at risk of malaria each year, and up to 200,000 babies die as a result. In malaria endemic areas, Plasmodium infections during pregnancy tend to remain asymptomatic yet causing significant problems like maternal anemia, low birth weight, premature births, miscarriage and still birth. Besides, asymptomatic carriers serve as silent reservoir of gametocytes for transmission by mosquito vectors. Early and accurate diagnosis of malaria with effective treatment and use of long-lasting insecticidal nets (LLINS) is the best strategy for prevention and control of complications during pregnancy and infant morbidity and mortality. However, laboratory diagnosis has relied on the identification of malaria parasites and parasite antigens in peripheral blood using Giemsa-stained microscopy or rapid diagnostic tests (RDTs). The aim of this study was to determine the prevalence of asymptomatic malaria parasite among pregnant women attending antenatal clinic at Mariya Sunusi maternity hospital Kano, Nigeria.
\end{abstract}

Methodology: A facility based cross-sectional study was conducted in Mariya Sunusi maternity hospital Kano, Nigeria from June, 2020 to July, 2020. Socio-demographic data were collected by using a semi-structured questionnaire. Plasmodium parasites were diagnosed by using Giemsa-stained blood smear microscopy and a rapid diagnostic test. Descriptive analysis was performed to obtain the frequency distribution of the variables.

Results: The result shows that of the total 248 pregnant women participated in this study, $10.8 \%$ and $7.6 \%$ were confirmed to be infected with Plasmodium species by microscopy and rapid diagnostic tests (RDTs), respectively.

Conclusion: The present study showed asymptomatic malaria is prevalent in pregnant women. The findings of the present study suggests the need of further malaria control strategies to screen the pregnant women for asymptomatic Plasmodium infection followed by prompt malaria treatment in the Antenatal care (ANC) service package. Such initiatives not only safeguard the pregnant women from malaria associated morbidities and mortalities but also the fetus and the newborns. As part of Antenatal care (ANC) service package, educating on the appropriate usage and benefits of the bed nets, and encouraging early Antenatal care $(A N C)$ attendance among pregnant women could enhance benefits for the women's health. RDTs can be used sufficiently for diagnosis of the asymptomatic malaria in areas where there is no access to light microscopy.

Keywords: Anaemia, Kano, Mariya Sunusi, Plasmodium species, pregnant women, Prevalence 


\section{INTRODUCTION}

Malaria is a disease caused by the protozoan parasites of the genus Plasmodium. The five species that commonly infect humans are: Plasmodium falciparum, Plasmodium vivax, Plasmodium ovale, Plasmodium malariae and Plasmodium knowlesi [1]. P. falciparum is found in the tropics and sub- tropics and it is the most important species as it is responsible for $50 \%$ of all morbidity and mortality from severe malaria. $P$. vivax is seen in tropics and subtropical areas and is less dangerous but more widespread. It is transmitted to humans by the bite of infected female Anopheles mosquito of more than 30 species [1]. In sub-Saharan Africa, Anopheles gambiae, Anopheles arabiensis and Anopheles funestus are the primary vectors of malaria parasites and show highly anthropophagic tendencies [1]. Malaria during pregnancy remains a major public health threat in sub-Saharan Africa where about 125 million pregnancies are at risk of malaria each year, and up to 200,000 babies die as a result [2]. Plasmodium falciparum is the principal cause of severe malaria while Plasmodium vivax is increasingly recognized as capable of causing severe disease [3-6]. According to the latest World Health Organization report of 2015, there were an estimated 214 million cases of malaria worldwide with 438,000 deaths. Ninety per cent of the deaths occurred in sub-Saharan Africa where pregnant women and children are significantly affected [3]. Every year about 30 million African women in malaria endemic areas become pregnant and are at risk of infection with malaria, and an estimated 75,000-200,000 infant deaths are reported due to malaria infection in pregnancy [7, 8]. Malaria, particularly due to $P$. falciparum, in pregnant women increases the risk of maternal death, miscarriage, stillbirth and neonatal death $[9,10]$. The impact of malaria during pregnancy may vary within a country depending on the intensity of malaria transmission. In areas of seasonal malaria transmission, pregnant women are three times more likely to suffer from severe malaria as compared to non-pregnant counterparts. In areas of stable malaria, adult pregnant women would have considerable acquired immunity and infection during pregnancy typically does not cause symptomatic malaria. The effect of malaria in pregnancy is primarily low birth weight and maternal anaemia $[11,12]$.
The World Health Organization (WHO) recommends a three-pronged approach to reduce the burden of malaria in pregnancy: (1) provision and promotion of insecticide treated bet nets (ITN) or long-lasting insecticidetreated bed nets (LLINS); (2) administration of intermittent preventive treatment with sulfadoxine-pyrimethamine (IPTp-SP) after the first trimester of pregnancy in areas with stable malaria transmission; and (3) prompt diagnosis and appropriate treatment of malaria [7, 13]. However, because of rising $P$. falciparum resistance to SP in sub-Saharan regions, the use of rapid diagnostic tests to screen women for malaria at the first or each antenatal visit and then treat is likely more sustainable than IPTp without diagnosis [14]. Currently, WHO strives to increase access to IPTp-SP for pregnant women in all areas with moderate to high malaria transmission in Africa, as part of antenatal care (ANC) service package [11].Early and accurate diagnosis with effective treatment is the best strategy to decrease malaria-related pregnancy complications and infant mortality. The current malaria diagnostic methods include Giemsa-based microscopy, rapid diagnostic tests (RDTs), polymerase chain reaction (PCR) and placental histology depending on the setting [15]. The poor performance of routine malaria diagnostic techniques including RDTs and microscopy contribute to the burden of malaria in pregnant women $[16,17]$. This is in large part due to the sequestration of the parasite in the placenta making the parasitaemia lower than usual in the peripheral blood. Therefore, nPCR which targets the small subunit ribosomal RNA (ssrRNA) is the better alternative diagnostic technique due to its high sensitivity (as low as 0.1 parasite/ $\mu 1$ of whole blood). However, nPCR it is not widely used for the diagnosis of malaria in resource-limited settings as it requires a very well equipped laboratory, and the cost of diagnosis is more expensive $[18,19]$.

Globally there are an estimated 219 million malaria cases and 435,000 deaths due to malaria each year with the highest mortality reported in Africa [20]. Malaria infection during pregnancy is a major public health problem in tropical and subtropical regions [21]. It affects an estimated 24 million pregnant women in sub-Saharan Africa annually [22]. In malaria-endemic areas, malaria is the cause for almost $25 \%$ of maternal deaths each year, with the greatest risk of infection and morbidity occurring in primiparous women, adolescents, and those co- 
infected with human immunodeficiency virus (HIV) [23]. Malaria during pregnancy may cause a variety of adverse consequences including maternal anaemia, placental accumulation of parasites, and low birth weight from prematurity and intrauterine growth retardation, congenital infection and infant mortality [24]. Asymptomatic infection with Plasmodium species is common in malaria endemic areas [25, 26]. The prevalence of asymptomatic parasitaemia reaches over $90 \%$ in children, in highly endemic areas of Africa [27]. Asymptomatic individuals, whether with a detectable parasitaemia by microscopy or below the microscopic detection level, can be a reservoir for transmission by Anopheles mosquitoes and may progress to symptomatic disease [27, 28]. Moreover, untreated asymptomatic malaria evolves in a chronic infection characterized by marked dyserythropoietic changes in the red cell precursors and increased erythrophagocytosis [29]. The efforts to reduce the burden of malaria require moving beyond the treatment of clinical infections to targeting transmission in the community by accurate identification of asymptomatic infections [30]. Each year at least 3 million pregnancies occur among women in malarious areas of Africa, most of who reside in areas of relatively stable malaria transmission [31]. The symptoms and complications of malaria during pregnancy differ with the intensity of malaria transmission and thus with the level of immunity the pregnant woman has acquired [32].

Malaria is the most deadly tropical infectious disease disproportionately affecting the poor, children under the age of 5 years, and pregnant women. There were an estimated 216 million episodes of malaria worldwide in 2010, of which approximately $81 \%$ or 174 million cases were in the African region [33].

In malaria endemic areas, a significant proportion of individuals have asymptomatic infection with Plasmodium species [34, 35] among whom pregnant women are at higher risk [36]. The sequestration of Plasmodium species in placenta is believed to be associated with low birth weight, preterm delivery, miscarriage, and still birth [37, 38]. Besides, asymptomatic carriers serve as silent reservoir of gametocytes for transmission by mosquito vectors [39, 40].

In Nigeria, malaria in pregnant women is a major public health problem where it accounts for more cases and deaths than any other country in the world. Malaria is a risk for $97 \%$ of Nigeria's population. The remaining 3\% of the population live in the malaria free highlands. There are an estimated 100 million malaria cases with over 300,000 deaths per year in Nigeria. This compares with 215,000 deaths per year in Nigeria from HIV/AIDS. Malaria contributes to an estimated $11 \%$ of maternal mortality [41]. Beyond the impact of malaria on children and pregnant women, it affects the general population. $100 \%$ of the total population of Nigeria is at risk of malaria and at least 50\% of the total population suffers from at least one episode of malaria each year [42].About $51 \%$ of malaria cases and deaths in Nigeria occurs in rural villages away from effective diagnostic or treatment facilities [42]. Malaria cases and deaths have been increasing in the country, mainly due to injudicious use of anti-malarial drugs, delayed health seeking, and reliance on the clinical judgment without laboratory confirmation in most of the peripheral health facilities [43].

To the best of our knowledge there has been no published study to attest the epidemiological data regarding asymptomatic malaria parasite among pregnant women in the study area. Therefore, the present study determined the prevalence of asymptomatic malaria parasite among pregnant women attending antenatal clinic at Mariya Sunusi maternity hospital Kano, Nigeria.

\section{Methodology}

\subsection{Study Area And Study Design}

The study was conducted at Mariya Sunusi maternity hospital Kano, Nigeria. Mariya Sunusi maternity hospital Kano is a government secondary health facility serving a population of about 1.5 million and having a patronage of about 300/day. It is located along Katsina road in Kano metropolis. The hospital caters for all maternity cases. A facility-based crosssectional study was conducted among apparently healthy pregnant women in medical laboratory department at Mariya Sunusi maternity hospital Kano, Nigeria from June, 2020 to July, 2020. Socio-demographic data were collected by using a semi-structured questionnaire. Plasmodium infection was diagnosed by using Giemsa-stained blood smear microscopy and a rapid diagnostic test (SD BIOLINE Malaria Ag Pf/Pv POCT, standard diagnostics, inc., Korea). 


\subsection{Sample Size Determination}

In this study, manual calculation of the sample size using Morgan and Krejcie (1970) formula was used for sample size determination as stated below:

$\mathrm{S}=\mathrm{X}^{2} \mathrm{NP}(1-\mathrm{P}) \div \mathrm{d}^{2}(\mathrm{~N}-1)+\mathrm{X}^{2} \mathrm{P}(1-\mathrm{P})$

Where:

$\mathrm{S}=$ Required sample size

$\mathrm{X}^{2}=$ The table value of the chi-square at desired confidence (3.841)

$\mathrm{N}=$ Study Population size (700)

$\mathrm{P}=$ Population proportion assumed to be 0.50 since this would provide maximum sample size

$\mathrm{d}^{2}=$ Degree of accuracy of the result expressed as proportion 0.050

$3.841 \times 700 \times 0.5 \times 0.5$

$0.0025 \times 699+3.841 \times 0.5 \times 0.5$

$\underline{672.175}=248$

2.70775

Hence 248 respondents

\subsection{Inclusion And Exclusion Criteria}

Pregnant women aged 18 years and above with absence of disease symptom/sign within the past 48 hours, axillary temperature $\leq 37.5^{\circ} \mathrm{c}$, permanent residents in the study area, and those willing to participate in the study and signed the informed consent were included. Individuals having taken anti-malarial drugs in the past six weeks prior to data collection, those undergoing any kind of long term medical treatments, and unwilling individuals were excluded from the study.

\subsection{Data Collection}

A pre-tested semi-structured questionnaire was administered by trained interviewer to obtain data on socio demographic characteristics of the pregnant women. Capillary blood samples were collected by a finger pricking using disposable lancet.

\subsection{Laboratory Investigations}

Thin and thick blood smears were prepared, stained with 3\% Giemsa and examined microscopically from each asymptomatic pregnant woman. Thin smears were considered positive for malaria if one or more malarial parasites were seen; and, negative if no asexual form of Plasmodium was observed in 200 high- power fields. On the other hand, thick blood films were taken as positive if one or more malaria parasites have been observed; and, negative if no parasites were seen after examining 1000 white blood cells.

The rapid diagnostic test used in this study was SD BIOLINE Malaria Ag P.f/P.v POCT standard diagnostics, Inc., Korea. This test is one step, rapid, qualitative, and differential test for the detection of HRP-II (Histidine-rich protein II) specific to $\mathrm{P}$. falciparum, and $\mathrm{pLDH}$ (Plasmodium lactate dehydrogenase) specific to P. vivax in a human blood sample.

\subsection{Quality Control}

Two experienced medical laboratory scientist individually examined the microscopic slides. Hundred microscopic fields of the thick smear were examined before concluding as negative. Discrepancy between the first and second readings was settled by a third senior microscopist, whose readings were considered final. The manufacturer's instruction was strictly followed for the RDTs. Blood smear microscopy readers were blinded to the result of RDTs.

\subsection{Data Analysis}

Data were analyzed using Statistical Package for Social Science (SPSS) software version 16.0 at that time with the help of the Statistician. The descriptive statistical method was used to analyze frequencies and percentages.

\section{RESUltS}

\subsection{Socio-demographic characteristics}

A total of 248 respondents were interviewed, giving $100 \%$ response rate. Among all, $110(44.4 \%)$ of respondents were 26-30 years of age. Majorities 198 (79.8\%) of the pregnant women were married.

$96(38.7 \%)$ of the subjects were Secundigravidae, 101(40.7\%) of the pregnant women were in the second trimester.168 $(67.7 \%)$ of the pregnant women uses Insecticide Treated Mosquito Net (ITN). The socioeconomic characteristics of the study showed that, among all respondents, 171(68.9\%) of respondents attended formal education, among this $101(40.7 \%)$ of respondents were primary school completed, $70(28.2 \%)$ of respondents were secondary school completed, while $77(31 \%)$ of respondents reported that they were took informal education (were illiterate and only 
Epidemiological Study on the Prevalence of Asymptomatic Malaria Parasite among Pregnant Women Attending Antenatal Clinic at Mariya Sunusi Maternity Hospital Kano, Nigeria

read and write). Similarly, results of occupational status of respondents indicated, $122(49.2 \%)$ of respondents were house wives, $60(24.2 \%)$ were Government employee, $16(6.4 \%)$ company employee and 50(20.2\%) were Merchants (Table 1).

Table 1. Socio demographic characteristics of respondents $(n=248)$

\begin{tabular}{|c|c|c|}
\hline Characteristics & Frequencies & $\begin{array}{c}\text { Percentages } \\
\%\end{array}$ \\
\hline \multicolumn{3}{|l|}{ Ages } \\
\hline $20-25$ & 72 & 29.0 \\
\hline $26-30$ & 110 & 44.4 \\
\hline $31-35$ & 50 & 20.2 \\
\hline $36+$ & 16 & 6.4 \\
\hline \multicolumn{3}{|l|}{ Marital status } \\
\hline Married & 198 & 79.8 \\
\hline Divorced & 33 & 13.3 \\
\hline Widowed & 17 & 6.9 \\
\hline \multicolumn{3}{|l|}{ Parity } \\
\hline Primigravid & 90 & 36.3 \\
\hline Secundigravid & 96 & 38.7 \\
\hline Multigravid & 62 & 25 \\
\hline \multicolumn{3}{|l|}{$\begin{array}{l}\text { Gestational } \\
\text { age }\end{array}$} \\
\hline $1^{\mathrm{st}}$ trimester & 87 & 35.1 \\
\hline $2^{\text {nd }}$ trimester & 101 & 40.7 \\
\hline $3^{\text {rd }}$ trimester & 60 & 24.2 \\
\hline \multicolumn{3}{|l|}{ Education } \\
\hline $\begin{array}{l}\text { Secondary and } \\
\text { above }\end{array}$ & 70 & 28.2 \\
\hline Primary & 101 & 40.7 \\
\hline $\begin{array}{l}\text { Can read and } \\
\text { write }\end{array}$ & 60 & 24.2 \\
\hline Illiterate & 17 & 6.9 \\
\hline \multicolumn{3}{|l|}{ Occupation } \\
\hline House Wife & 122 & 49.2 \\
\hline $\begin{array}{l}\text { Government } \\
\text { Employee }\end{array}$ & 60 & 24.2 \\
\hline $\begin{array}{l}\text { Company } \\
\text { Employee }\end{array}$ & 16 & 6.4 \\
\hline Merchants & 50 & 20.2 \\
\hline \multicolumn{3}{|l|}{ ITN use } \\
\hline Use always & 168 & 67.7 \\
\hline Use rarely & 19 & 7.7 \\
\hline Do not use & 61 & 24.6 \\
\hline
\end{tabular}

According to age, pregnant women aged 26-30 years had highest infection rate of $11(4.4 \%)$ by microscopy and $9(3.6 \%)$ by RDT, followed by 8 (3.2\%) by microscopy and $5(2.0 \%)$ by RDT for age group $20-25$ years. 5 (2.0\%) by microscopy and $3(1.2 \%)$ by RDT for age group 31-35 years, $3(1.2 \%)$ by microscopy and $2(0.8 \%)$ by RDT for age group 36+ (Table 2).

Table 2. Prevalence of malaria parasite among pregnant women according to age group $(n=248)$

\begin{tabular}{|c|c|c|c|c|c|}
\hline Ages & $\begin{array}{c}\text { No. } \\
\text { Exami } \\
\text { ned } \\
(\%)\end{array}$ & $\begin{array}{c}\text { Micros } \\
\text { copy } \\
\text { No. } \\
\text { Positive } \\
(\%) \\
\end{array}$ & $\begin{array}{c}\text { Total } \\
(\%)\end{array}$ & $\begin{array}{c}\text { RDT } \\
\text { No. } \\
\text { Positi } \\
\text { ve } \\
(\%) \\
\end{array}$ & $\begin{array}{c}\text { Tota } \\
1 \\
(\%)\end{array}$ \\
\hline $\begin{array}{l}20- \\
25\end{array}$ & $\begin{array}{l}60 \\
(24.2 \\
\%)\end{array}$ & $\begin{array}{l}8 \\
(3.2 \%)\end{array}$ & $\begin{array}{l}8 \\
(3.2 \\
\%)\end{array}$ & $\begin{array}{l}5 \\
(2.0 \\
\%)\end{array}$ & $\begin{array}{l}5 \\
(2.0 \\
\%)\end{array}$ \\
\hline $\begin{array}{l}26- \\
30\end{array}$ & $\begin{array}{l}110 \\
(44.4 \\
\%)\end{array}$ & $\begin{array}{l}11 \\
(4.4 \%)\end{array}$ & $\begin{array}{l}19 \\
(7.6 \\
\%)\end{array}$ & $\begin{array}{l}9 \\
(3.6 \\
\%)\end{array}$ & $\begin{array}{l}14 \\
(5.6 \\
\%)\end{array}$ \\
\hline $\begin{array}{l}31- \\
35\end{array}$ & $\begin{array}{l}50 \\
(20.2 \\
\%)\end{array}$ & $\begin{array}{l}5 \\
(2.0 \%)\end{array}$ & $\begin{array}{l}24 \\
(9.6 \\
\%)\end{array}$ & $\begin{array}{l}3 \\
(1.2 \\
\%)\end{array}$ & $\begin{array}{l}17 \\
(6.8 \\
\%)\end{array}$ \\
\hline $36+$ & $\begin{array}{l}28 \\
(11.3 \\
\%)\end{array}$ & $\begin{array}{l}3 \\
(1.2 \%)\end{array}$ & $\begin{array}{l}27 \\
(10.8 \\
\%)\end{array}$ & $\begin{array}{l}2 \\
(0.8 \\
\%)\end{array}$ & $\begin{array}{l}19 \\
(7.6 \\
\%)\end{array}$ \\
\hline
\end{tabular}

According to parity, primigravids had the highest infection rate with $14(5.6 \%)$ by microscopy and $9(3.6 \%)$ by RDT being infected. This was followed by women of 2 nd pregnancy with prevalence of $8(3.2 \%)$ by microscopy and $7(2.8 \%)$ by RDT. Women of $3^{\text {rd }}$ pregnancy and above had the least prevalence of $5(2.0 \%)$ by microscopy and 3 $(1.2 \%)$ by RDT (Table 3 ).

Table 3. Prevalence of malaria parasite among pregnant women according to Parity $(n=248)$

\begin{tabular}{|c|c|c|c|c|c|}
\hline Parity & $\begin{array}{c}\text { No. } \\
\text { Exam } \\
\text { ined } \\
(\%)\end{array}$ & $\begin{array}{c}\text { Micros } \\
\text { copy } \\
\text { No. } \\
\text { Positiv } \\
\text { e }(\%)\end{array}$ & $\begin{array}{c}\text { Tota } \\
1 \\
(\%)\end{array}$ & $\begin{array}{c}\text { RD } \\
\text { T } \\
\text { No. } \\
\text { Posi } \\
\text { tive } \\
(\%)\end{array}$ & $\begin{array}{c}\text { Tot } \\
\text { al } \\
(\%)\end{array}$ \\
\hline $\begin{array}{l}\text { Primigra } \\
\text { vid }\end{array}$ & $\begin{array}{l}90 \\
(36.3 \\
\%)\end{array}$ & $\begin{array}{l}14 \\
(5.6 \%)\end{array}$ & $\begin{array}{l}14 \\
(5.6 \\
\%)\end{array}$ & $\begin{array}{l}9 \\
(3.6 \\
\%)\end{array}$ & $\begin{array}{l}9 \\
(3.6 \\
\%)\end{array}$ \\
\hline $\begin{array}{l}\text { Secundi } \\
\text { gravid }\end{array}$ & $\begin{array}{l}96 \\
(38.7 \\
\%) \\
\end{array}$ & $\begin{array}{l}8 \\
(3.2 \%)\end{array}$ & $\begin{array}{l}22 \\
(8.8 \\
\%) \\
\end{array}$ & $\begin{array}{l}7 \\
(2.8 \\
\%) \\
\end{array}$ & $\begin{array}{l}16 \\
(6.4 \\
\%) \\
\end{array}$ \\
\hline $\begin{array}{l}\text { Multigra } \\
\text { vid }\end{array}$ & $\begin{array}{l}62 \\
(25 \%)\end{array}$ & $\begin{array}{l}5 \\
(2.0 \%)\end{array}$ & $\begin{array}{l}27 \\
(10.8 \\
\%)\end{array}$ & $\begin{array}{l}3 \\
(1.2 \\
\%)\end{array}$ & $\begin{array}{l}19 \\
(7.6 \\
\%)\end{array}$ \\
\hline
\end{tabular}

It was also observed that according to gestational age of pregnancy, women of second trimester had the highest prevalence of 12 $(4.8 \%)$ by microscopy and women of $1^{\text {st }}$ trimester $10(4.0 \%)$ by RDT. This was followed by first trimester $9(3.6 \%)$ by microscopy and second trimester $6(2.4 \%)$ by RDT. The least was $6(2.4 \%)$ by microscopy and $3(1.2 \%)$ by RDT for third trimester (Table 4).

Table 4. Prevalence of malaria parasite among pregnant women according to Gestational age $(n=248)$ 


\begin{tabular}{|c|c|c|c|c|c|}
\hline $\begin{array}{c}\text { Gestati } \\
\text { onal } \\
\text { age }\end{array}$ & $\begin{array}{c}\text { No. } \\
\text { Exami } \\
\text { ned } \\
(\%)\end{array}$ & $\begin{array}{c}\text { Micros } \\
\text { copy } \\
\text { No. } \\
\text { Positiv } \\
\text { e }(\%)\end{array}$ & $\begin{array}{l}\text { Tota } \\
\text { I }(\%)\end{array}$ & $\begin{array}{c}\text { RDT } \\
\text { No. } \\
\text { Posit } \\
\text { ive } \\
(\%)\end{array}$ & $\begin{array}{c}\text { Tot } \\
\text { al } \\
(\%)\end{array}$ \\
\hline $\begin{array}{l}1^{\text {st }} \\
\text { trimest } \\
\text { er }\end{array}$ & $\begin{array}{l}88 \\
(35.4 \\
\%)\end{array}$ & $\begin{array}{l}9 \\
(3.6 \%)\end{array}$ & $\begin{array}{l}9 \\
(3.6 \\
\%)\end{array}$ & $\begin{array}{l}10 \\
(4.0 \\
\%)\end{array}$ & $\begin{array}{l}10 \\
(4.0 \\
\%)\end{array}$ \\
\hline $\begin{array}{l}2^{\text {nd }} \\
\text { trimest } \\
\text { er }\end{array}$ & $\begin{array}{l}110 \\
(44.4 \\
\%)\end{array}$ & $\begin{array}{l}12 \\
(4.8 \%)\end{array}$ & $\begin{array}{l}21 \\
(8.4 \\
\%)\end{array}$ & $\begin{array}{l}6 \\
(2.4 \\
\%)\end{array}$ & $\begin{array}{l}16 \\
(6.4 \\
\%)\end{array}$ \\
\hline $\begin{array}{l}3^{\text {rd }} \\
\text { trimest } \\
\text { er }\end{array}$ & $\begin{array}{l}50 \\
(20.2 \\
\%)\end{array}$ & $\begin{array}{l}6 \\
(2.4 \%)\end{array}$ & $\begin{array}{l}27 \\
(10.8 \\
\%)\end{array}$ & $\begin{array}{l}3 \\
(1.2 \\
\%)\end{array}$ & $\begin{array}{l}19 \\
(7.6 \\
\%)\end{array}$ \\
\hline
\end{tabular}

\section{DISCUSSION}

The present study aimed at determined the prevalence of asymptomatic malaria parasite among pregnant women attending antenatal clinic at Mariya Sunusi maternity hospital Kano, Nigeria.

In the present study, the prevalence of asymptomatic Plasmodium infection among pregnant women was $\mathbf{1 0 . 8 \%}$ and $\mathbf{7 . 6 \%}$ by using Giemsa-stained blood smear microscopy and RDT respectively. This prevalence is in agreement with the report of malaria prevalence among pregnant women ranged from $10 \%$ to $65 \%$ in malaria endemic areas [44]. However this prevalence was in line with the finding reported from the rural surroundings of Arbaminch town, South Ethiopia, which was 9.1\% and $9.7 \%$ by microscopy and RDT, respectively among pregnant women [45].

The finding of the present study corroborates the findings of similar studies reported from other parts of Ethiopia [46, 47]. However it is lower than the finding of $27 \%$ by RDTs and $23 \%$ by microscopy reported from Democratic Republic of the Congo [48], and is higher than the prevalence of $3.1 \%$ by microscopy and $4.8 \%$ by RDTs reported from Nigeria [49]. This might be due to differences in geographical locations or transmission pattern. In different geographical locations, there are unique malaria transmission patterns that result in different immune acquisition capacity of the residents. Individuals living in higher malaria transmission areas have greater chance of developing asymptomatic malaria because they get frequent infections that can highly boost immunity against malaria, while those in low transmission areas have low infection frequency thus there may occur low prevalence of asymptomatic malaria [50].
The prevalence of asymptomatic Plasmodium infection was higher using microscopy than RDT which disagrees with a report from the rural surroundings of Arbaminch Town, South Ethiopia [45]. However, the finding was consistent with the study findings reported from Tanzania and Myanmar [51, 52].

The use of Insecticide Treated Mosquito Net (ITN) in the present study is $67.7 \%$, though usage pattern differs among the study subjects. This is lower than the report of $89.6 \%$ by Getachew and his colleagues [46]. There was a strong association between increasing gravidity and decreasing rates of parasitemia.

This agrees with findings of similar studies from sub-Saharan African countries where the prevalence of asymptomatic Plasmodium infection was significantly higher in primigravidae than the multigravidae [53, 54]. It might be linked to infection-specific immunological factors. Some Plasmodium infected erythrocytes sequester in the maternal placenta by producing surface antigens, mainly variant surface antigen, that adhere to chondroitin sulphate-A (CSA) receptors expressed by syncytiotrophoblasts in the placenta. Primigravidae and secundigravidae are more susceptible to infection, as they lack these anti-adhesion antibodies against CSA binding parasites, which develop only after successive pregnancies [55].

In the present study there was significant difference in the rate of asymptomatic malaria parasitemia with respect to age of the pregnant women. However, the findings of some similar studies [56, 57] suggested that peripheral parasitemia was higher in pregnant women of younger age groups than old ages. This contrast might be due to differences in the sample size, sampling technique, physiologic and biochemical factors of pregnant women and the study setting such as geographical differences, altitude, temperature, and age categorization scheme.

Malaria has moderate to high transmission pattern in Nigeria. In countries where malaria has moderate to high transmission, WHO recommends intermittent preventive treatment with sulfadoxine pyrimethamine (IPTp-SP) for pregnant women as part of the Antenatal care (ANC) services, which does apply for Nigeria[58]. Hence, screening of pregnant women for asymptomatic Plasmodium infection should be the way forward to fight against 
malaria in pregnancy and its consequences on fetus.

\section{CONCLUSION}

The present study showed asymptomatic malaria is prevalent in pregnant women. The findings of the present study suggests the need of further malaria control strategies to screen the pregnant women for asymptomatic Plasmodium infection followed by prompt malaria treatment in the Antenatal care (ANC) service package. Such initiatives not only safeguard the pregnant women from malaria associated morbidities and mortalities but also the fetus and the newborns. As part of Antenatal care (ANC) service package, educating on the appropriate usage and benefits of the bed nets, and encouraging early Antenatal care (ANC) attendance among pregnant women could enhance benefits for the women's health. RDTs can be used sufficiently for diagnosis of the asymptomatic malaria in areas where there is no access to light microscopy.

\section{ACKNOWLEDGMENTS}

I am grateful to thank the study participants for their cooperation in providing the information and blood sample necessary for this study and acknowledge the team of research assistants.

\section{ETHICAL CONSIDERATIONS}

This study was conducted only after obtaining approval from research ethics committee of the hospital.

\section{REFERENCES}

[1] World Health Organization (2011).World malaria report. Geneva, Switzerland; 32-42.

[2] Dellicour S, Tatem AJ, Guerra CA, Snow RW, Ter Kuile FO. (2007). Quantifying the Number of Pregnancies at Risk of Malaria in 2007: A Demographic Study. PLoS Med (2010); 7(1): e1000221. Doi: 10.1371/journal. Pmed.1000221 PMID: 20126256

[3] World Health Organization (2015).World malaria report. Geneva Strydom AK, Ismail F, Frean J. Plasmodium ovale: a case of not-sobenign tertian malaria. Malar J. (2014); 13:85.

[4] Zubairi AB, Nizami S, Raza A, Mehraj V, Rasheed AF, Ghanchi NK, et al. Severe Plasmodium vivax malaria in Pakistan. Emerg Infect Dis. (2013); 19:1851-4.

[5] Rahimi BA, Thakkinstian A, White NJ, Sirivichayakul C, Dondorp AM, Chokejindachai W. Severe vivax malaria: a systematic review and meta-analysis of clinical studies since 1900. Malar J. (2014); 13:481.
[6] Marchesini P, Crawley J. Reducing the burden of malaria in pregnancy.MERA IV, supporting agency-Roll Back Malaria, World Health Organization; (2004).

[7] Steketee RW, Nahlen BL, Parise ME, Menendez C. The burden of malaria in pregnancy in malaria-endemic areas. Am J Trop Med Hyg. (2001); 64:28-35.

[8] De Beaudrap P, Turyakira E, White LJ, Nabasumba C, Tumwebaze B, Muehlenbachs $\mathrm{A}$, et al. Impact of malaria during pregnancy on pregnancy outcomes in a Ugandan prospective cohort with intensive malaria screening and prompt treatment. Malar J. (2013);12:139.

[9] Luxemburger C, McGready R, Kham A, Morison L, Cho T, Chongsuphajaisiddhi T, et al. Effects of malaria during pregnancy on infant mortality in an area of low malaria transmission. Am J Epidemiol. (2001); 154:459-65.

[10] WHO/UNICEF. The Africa malaria report 2003. Geneva: World Health Organization; 2003.

[11] Newman RD, Hailemariam A, Jimma D, Degifie A, Kebede D, Rietveld AE, et al. Burden of malaria during pregnancy in areas of stable and unstable transmission in Ethiopia during a non-epidemic year. $\mathbf{J}$ Infect Dis. (2003);187:1765-72.

[12] Pell C, Meñaca A, Afrah NA, Manda-Taylor L, Chatio S, Were F, et al. Prevention and management of malaria during pregnancy: findings from a comparative qualitative study in Ghana, Kenya and Malawi. Malar J. (2013);12:247.

[13] Van Eijk AM, Hill J, Noor AM, Snow RW, Ter Kuile FO. Prevalence of malaria infection in pregnant women compared with children for tracking malaria transmission in sub-Saharan Africa: a systematic review and meta-analysis. Lancet Glob Health. (2015);3:e617-28.

[14] Fried M, Muehlenbachs A, Duffy PE. Diagnosing malaria in pregnancy: an update. Expert Rev Anti Infect Ther. (2012) ;10:117787.

[15] Mayor A, Moro L, Aguilar R, Bardaj A, Cistero P, Serra-Casas E, et al. How hidden can malaria be in pregnant women? Diagnosis by microscopy, placental histology, polymerase chain reaction and detection of histidine-rich protein 2 in plasma. Clin Infect Dis. (2012) ;54:1561-8.

[16] Tangpukdee N, Duangdee C, Wilairatana P, Krudsood S. Malaria diagnosis: a brief review. Korean J Parasitol. (2009) ;47:93-102.

[17] WHO. Malaria diagnostics technology and market landscape. 2nd ed. Geneva: World Health Organization; (2014). 
[18] Mens PF, van Amerongen A, Sawa P, Kager PA. Schallig DFH. Molecular diagnosis of malaria in the field: development of a novel 1step nucleic acid lateral flow immunoassay for the detection of all 4 human Plasmodium spp. and its evaluation in Mbita, Kenya. Diagn Microbiol Infect Dis. (2008); 61:421-7.

[19] WHO. World malaria report 2018. Geneva: World Health Organization; (2018).

[20] Adefioye OA, Adeyeba OA, Hassan WO, Oyeniran OA. Prevalence of malaria parasite infection among pregnant women in Osogbo, Southwest, Nigeria. American-Eurasian J Sci Res. (2007); 2:43-5.

[21] Uneke CJ. Impact of placental Plasmodium falciparum malaria on pregnancy and perinatal outcome in sub-Saharan Africa: I: introduction to placental malaria. Yale J Biol Med. (2007); 80:39-50.

[22] Schantz-Dunn J, Nour NM. Malaria and pregnancy: a global health perspective. Rev Obstet Gynecol. (2009);2:186-92.

[23] Steketee RW, Nahlen BL, Parise ME, Menendez $C$. The burden of malaria in pregnancy in malaria-endemic areas. Am J Trop Med Hyg. (2001);64(Suppl 1):28-35.

[24] Nega D, Dana D, Tefera T, Eshetu T. Prevalence and predictors of asymptomatic malaria parasitemia among pregnant women in the rural surroundings of Arbaminch Town, South Ethiopia. PLoS ONE. (2015); 10:e0123630.

[25] Adepeju I. Prevalence of malaria parasite among asymptomatic and symptomatic students of Federal University of Technology, Akure, Ondo State. Br J Res. (2017); 4:1-5.

[26] Njama-Meya D, Kamya MR, Dorsey G. Asymptomatic parasitaemia as a risk factor for symptomatic malaria in a cohort of Ugandan children. Trop Med Int Health. (2004) ; 9:8628.

[27] Golassa L, Baliraine FN, Enweji N, Erko B, Swedberg G, Aseffa A. Microscopic and molecular evidence of the presence of asymptomatic Plasmodium falciparum and Plasmodium vivax infections in an area with low, seasonal and unstable malaria transmission in Ethiopia. BMC Infect Dis. (2015); 15:310.

[28] Matangila JR, Lufuluabo J, Ibalanky AL, da Luz RA, Lutumba P, Van Geertruyden JP. Asymptomatic Plasmodium falciparum infection is associated with anaemia in pregnancy and can be more cost-effectively detected by rapid diagnostic test than by microscopy in Kinshasa, Democratic Republic of the Congo. Malar J. (2014); 13:132.

[29] Wu L, van den Hoogen LL, Slater H, Walker PG, Ghani AC, Drakeley CJ, et al. Comparison of diagnostics for the detection of asymptomatic Plasmodium falciparum infections to inform control and elimination strategies. Nature. (2015); 528:86-93.

[30] Brabin, B. J. (2000). The risks and severity of malaria in pregnant women in Africa. Report no 1. (2000). Geneva: WHO: 1-43.

[31] Perlmann, P., and Troye-Blomberg, M. (2000). Immunity to malaria. Am. J. Immunology, 80: 229-242.

[32] WHO. World Malaria Report (2011). Geneva, Switzerland: World Health Organization

[33] Dal-Bianco MP, Koster KB, Kombila UD, Kun JF, Grobusch MP, Ngoma GM, et al. High prevalence of asymptomatic Plasmodium falciparum infection in Gabonese adults. Am J Trop Med Hyg (2007); 77: 939-42. PMID: 17984357

[34] Baliraine FN, Afrane YA, Amenya DA, Bonizzoni M, Menge DM, Zhou G et al. High prevalence of asymptomatic Plasmodium falciparum infections in a highland area of western Kenya: a cohort study. J Infect Dis (2009); 200:66-74. Doi: 10.1086/599317 PMID: 19476434

[35] Khan WA, Galagan SR, Prue CS, Khyang J, Ahmed S, Ram M, et al. Asymptomatic Plasmodium falciparum Malaria in Pregnant Women in the Chittagong Hill Districts of Bangladesh. PLoS ONE (2014); 9(5): e98442. Doi: 10.1371/journal.pone.0098442 PMID: 24858193

[36] Sullivan AD, Nyirenda T, Cullinan T, Taylor T, Harlow SD, James SA, et al. Malaria infection during pregnancy: intrauterine growth retardation and preterm delivery in Malawi. J Infect Dis (1999); 179:1580-1583. PMID: 10228088

[37] Verhoeff FH, Brabin BJ, Chimsuku L, Kazembe P, Broad head RL. Malaria in pregnancy and its consequences for the infant in rural Malawi. Ann Trop Med Parasitol (1999); 93(Suppl 1):S25-S33. PMID: 10715686

[38] Alves FP, Gil LH, Marrelli MT, Ribolla PE, Camargo EP, Da Silva LH. Asymptomatic carriers of Plasmodium species as infection source for malaria vector mosquitoes in the Brazilian Amazon. J Med Entomol (2005); 42:777-779. PMID: 16363160.

[39] Cucunuba ZM, Guerrab ANP, Riverab JA, Nichollsa RNS. Comparison of Asymptomatic Plasmodium species. Infection in Two MalariaEndemic Colombian Locations. Trans R Soc Trop Med Hyg (2013); 107(2):129-136. doi: 10.1093/trstmh/trs021 PMID: 2322295.

[40] Federal Ministry of Health. A road map for malaria control in Nigeria, a bridged version, Abuja. Strategic Plan. (2009-2013); Yahian Press Ltd. (2010); 155. 
[41] World Health Organization. World Malaria Report (2010).

[42] Vander, H. W, Presmasiri, D. A., and Wickremasinghe, A. R. (2005). Current Trends in the Control of Malaria: Case Management. $J$. Trop. Med. Public Health. 29:242-245.

[43] Steketee RW, Nahlen BL, Parise ME, Menendez $C$. The burden of malaria in pregnancy in malaria endemic areas. Am J Trop Med Hyg (2001); 64:28-35. PMID: 11425175

[44] Nega D, Dana D, Tefera T, Eshetu T. Prevalence and predictors of asymptomatic malaria parasitemia among pregnant women in the rural surroundings of Arbaminch Town, South Ethiopia. PLoS ONE. (2015); 10:e0123630.

[45] Getachew M, Yewhalaw D, Tafess K, Getachew Y, Zeynudin A. Anaemia and associated risk factors among pregnant women in Gilgel Gibe dam area, Southwest Ethiopia. Parasites and Vectors (2012); 5:296. Doi: 10.1186/1756-3305-5-296 PMID: 23244514

[46] Newman RD, Hailemariam A, Jimma D, Degifie A, Kebede D, Rietveld AE, et al. Burden of Malaria during Pregnancy in Areas of Stable and Unstable Transmission in Ethiopia during a Non-epidemic Year. J Infect Dis (2003); 187:1765-72. PMID: 12751034

[47] Khan WA, Galagan SR, Prue CS, Khyang J, Ahmed S, Ram M, et al. Asymptomatic Plasmodium falciparum Malaria in Pregnant Women in the Chittagong Hill Districts of Bangladesh. PLoS ONE (2014); 9(5): e98442. Doi: 10.1371/journal.pone.0098442 PMID: 24858193

[48] Isah AY, Amanabo MA, Ekele BA. Prevalence of malaria parasitaemia amongst asymptomatic pregnant women attending a Nigerian Teaching Hospital. Ann Afr Med (2011); 10:171-4. Doi: 10.4103/1596- 3519.82070 PMID: 21691026

[49] Laishram DD, Sutton PL, Nanda N, Sharma VL, Sobti RC, Carlton JM, et al. The complexities of malaria disease manifestations with a focus on asymptomatic malaria. Malar $\mathbf{J}$ (2012); 11:29. doi: 10.1186/1475- 2875-11-29 PMID: 22289302

[50] Nzobo BJ, Ngasala BE, Kihamia CM. Prevalence of asymptomatic malaria infection and use of different malaria control measures among primary school children in Morogoro Municipality, Tanzania. Malar J. (2015); 14:491.

[51] Zaw MT, Thant M, Hlaing TM, Aung NZ, Thu $\mathrm{M}$, Phumchuea $\mathrm{K}$, et al. Asymptomatic and sub-microscopic malaria infection in Kayah State, eastern Myanmar. Malar J. (2017); 16:138.

[52] Okafor IM, Mbah M, Usanga EA. The Impact of Anaemia and Malaria Parasite Infection in Pregnant Women. Nigerian Perspective. J Dental Med Sci (2012); 1(1):34-8.

[53] Geertruyden JPV, Ntakirutimana D, Erhart A, Rwagacondo C, Kabano A, D'Alessandro U. Malaria infection among pregnant women attending antenatal clinics in six Rwandan districts. Trop Med Int Health (2005); 10:6818. PMID: 15960707

[54] Fried M, Nosten F, Brockman A, Brabin BJ, Duffy PE. Maternal antibodies block malaria. Nature (1998); 95:851-852.

[55] Federal Democratic Republic of Ethiopia Ministry of Health. National Malaria Guidelines. 3rd Edition. Federal Democratic Republic Of Ethiopia. Addis Ababa, Ethiopia (2012).

[56] Bouyou-Akotet MK, Ionete-Collard DE, Mabika-Manfoumbi M, Kendjo E, Matsiegui PB, Mavoungou E, et al. Prevalence of Plasmodium falciparum Infection in pregnant women in Gabon. Malar J (2003); 2:18. PMID: 12919637

[57] WHO policy brief for the implementation of intermittent preventive treatment of malaria in pregnancy using sulfadoxine-pyrimethamine (IPTp-SP) April (2013) (revised January 2014).

Citation: Epidemiological Study on the Prevalence of Asymptomatic Malaria Parasite among Pregnant Women Attending Antenatal Clinic at Mariya Sunusi Maternity Hospital Kano, Nigeria. Ahmad Salisu Aliyu, Ahmed Habibu Badawi, Hussaini Mohammed, Nuru Yakubu Umar, Samira Shehu.ARC Journal of Public Health and Community Medicine. 2020; 5(2):30-38. DOI: doi.org /10.20431/ 2456-0596.0502004.

Copyright: (C) 2020 Authors. This is an open-access article distributed under the terms of the Creative Commons Attribution License, which permits unrestricted use, distribution, and reproduction in any medium, provided the original author and source are credited. 